\title{
KANDUNGAN BETAKAROTEN, PROTEIN, KALSIUM, DAN UJI KESUKAAN CRACKERS DENGAN SUBSTITUSI TEPUNG UBI JALAR KUNING (IPOMOEA BATATAS L.) DAN IKAN TERI NASI (STOLEPHORUS SP.) UNTUK ANAK KEP DAN KVA
}

\author{
Latifah Nur Aisiyah, Ninik Rustanti ${ }^{*}$ \\ Program Studi Ilmu Gizi Fakultas Kedokteran Universitas Diponegoro \\ Jl.Dr.Sutomo No.14, Semarang, Telp (024) 8453708, Email : gizifk@ undip.ac.id
}

\begin{abstract}
Background : The consumption increased of food high in protein and betacaroten may be overcame protein energy malnutrition (PEM) and vitamin A deficiency (VAD) in children. Besides, increation of consumption high calcium food can be helped children growth processed. Yellow sweet potato flour was ingredient food that high of betacaroten, whereas dried anchovy flour was ingredient food that high protein and calcium. The substitution crackers with yellow sweet potato and dried anchovy flour can be expected as alternative diet that high protein, betacaroten and calcium.

Objective : To analyzed the effect of yellow sweet potato and dried anchovy flour substitution on protein, betacaroten, calcium and preference test of crackers.

Method: A randomized two factorial experimental design studied, they were yellow sweet potato flour substitution $(5 \%, 10 \%$, and 15\%) and dried anchovy flour substitution (5\% and 10\%). Statistical analyzed of protein, betacaroten and calcium used Anova Two Ways and preference test used Friedman test continued with Wilcoxon test.

Result : Crackers with 5\% yellow sweet potato flour and 5\% dried anchovy flour substitution have the highest protein level (10,25\% per 100g). Crackers with $15 \%$ yellow sweet potato flour and $10 \%$ dried anchovy flour

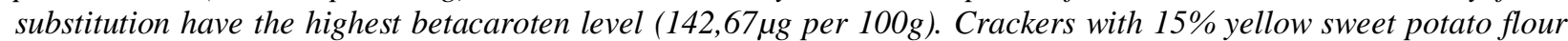
and $10 \%$ dried anchovy flour substitution have the highest calcium level (46,07mg per 100g). Yellow sweet potato and dried anchovy flour substitution on crackers had significant effect on aroma, taste, and colour, but had no effect on texture.

Conclusion : Based on value of the nutrients content and preference test, the recommend crackers is the crackers with $15 \%$ yellow sweet potato flour and $10 \%$ dried anchovy flour substitution.
\end{abstract}

Keywords: Yellow sweet potato flour; dried anchovy flour; protein; betacaroten; calcium; preference test

\section{ABSTRAK}

Latar Belakang : Peningkatan konsumsi pangan tinggi protein dan betakaroten diharapkan dapat menanggulangi Kekurangan Energi Protein (KEP) dan Kekurangan Vitamin A (KVA) pada anak. Selain itu, peningkatan konsumsi pangan tinggi kalsium dapat membantu proses pertumbuhan anak. Tepung ubi jalar kuning merupakan bahan pangan tinggi betakaroten, sedangkan tepung ikan teri nasi merupakan bahan pangan tinggi protein dan kalsium. Crackers yang disubstitusi tepung ubi jalar kuning dan tepung ikan teri nasi diharapkan mampu menjadi pangan alternatif diet tinggi protein, betakaroten, dan kalsium.

Tujuan : Menganalisis pengaruh substitusi tepung ubi jalar kuning dan tepung ikan teri nasi terhadap kadar protein, betakaroten, kalsium, dan uji kesukaan crackers.

Metode : Merupakan penelitian eksperimental dengan rancangan acak lengkap dua faktor yaitu substitusi tepung ubi jalar kuning $(5 \%, 10 \%$, dan 15\%) dan tepung ikan teri nasi (5\% dan 10\%). Analisis statistik dari kadar protein, betakaroten, dan kalsium menggunakan uji Anova Two Ways sedangkan uji kesukaan menggunakan uji Friedman dengan dilanjutkan uji Wilcoxon.

Hasil : Kadar protein tertinggi pada crackers dengan substitusi tepung ubi jalar kuning 5\% dan tepung ikan teri nasi $5 \%$ yaitu 10,25\% per $100 \mathrm{~g}$. Kadar betakaroten tertinggi pada crackers dengan substitusi tepung ubi jalar kuning $15 \%$ dan tepung ikan teri nasi $10 \%$ yaitu $142,67 \mu \mathrm{g}$ per $100 \mathrm{~g}$. Kadar kalsium tertinggi pada crackers dengan substitusi tepung ubi jalar kuning 15\% dan tepung ikan teri nasi 10\% yaitu 46,07mg per 100g. Substitusi tepung ubi jalar kuning dan tepung ikan teri nasi berpengaruh nyata terhadap aroma, rasa, dan warna, tetapi tidak berpengaruh nyata terhadap tekstur crackers.

Simpulan : Berdasarkan nilai gizi dan uji kesukaan, crackers yang direkomendasikan adalah crackers dengan substitusi tepung ubi jalar kuning $15 \%$ dan tepung ikan teri nasi $10 \%$.

Kata kunci : Tepung ubi jalar kuning; tepung ikan teri nasi; protein; betakaroten; kalsium; uji kesukaan

\footnotetext{
${ }^{*)}$ Penulis Penanggungjawab
} 


\section{PENDAHULUAN}

Kekurangan Vitamin A (KVA) masih menjadi masalah gizi pada seluruh dunia. Kekurangan vitamin A (KVA) dapat mengganggu sistem kekebalan sehingga meningkatkan risiko sakit dan kematian. KVA dalam waktu yang lama dapat menyebabkan kebutaan, xeroftalmia ringan pada anak-anak yang berhubungan dengan peningkatan morbiditas dan mortalitas. Diperkirakan 250.000 sampai 500.000 anak KVA mengalami kebutaan setiap tahunnya. ${ }^{1}$

Selain KVA, Kekurangan Energi Protein (KEP) juga masih menjadi masalah gizi utama di Indonesia. KEP merupakan suatu keadaan malnutrisi yang disebabkan defisiensi zat gizi makro, yaitu energi dan protein. Hasil Riset Kesehatan Dasar (RISKESDAS) tahun 2010 menunjukkan prevalensi KEP pada anak usia 6-12 tahun sebesar $12,2 \% .^{2}$ KEP dapat menyebabkan gangguan pertumbuhan dan perkembangan mental anak, serta menurunkan sistem kekebalan tubuh anak. $^{3}$

Untuk mengatasi masalah KEP dan KVA, upaya penanggulangan yang dilakukan antara lain fortifikasi pangan, peningkatan konsumsi bahan pangan sumber protein dan vitamin A, pemberian makanan tambahan (PMT), pemberian kapsul vitamin A bagi balita, pemantauan status gizi, dan diversifikasi pangan dan gizi. ${ }^{4}$

Salah satu alternatif makanan yang dapat digunakan untuk fortifikasi pangan yaitu crackers. Saat ini crackers menjadi makanan yang disukai oleh anak. Produk crackers saat ini mengalami perkembangan dengan variasi campuran antara tepung terigu sebagai bahan baku utama dengan bahan-bahan makanan lainnya yang bertujuan meningkatkan kandungan gizi crackers tersebut. ${ }^{5}$

Bahan makanan yang dapat dimanfaatkan untuk fortifikasi vitamin A, diantaranya ubi jalar kuning. ${ }^{6}$ Ubi jalar kuning (Ipomoea batatas L.) memiliki kandungan betakaroten sebesar $2900 \mu \mathrm{g} / 100 \mathrm{~g}$. Betakaroten merupakan salah satu karotenoid (provitamin A) yang banyak terdapat dalam bahan makanan disamping karotenoid lain, yaitu betakaroten, $\alpha$-karoten, dan $\beta$-cryptoxanthin. ${ }^{7}$

Salah satu alternatif pengolahan ubi jalar kuning yang dapat dilakukan adalah penepungan. Tepung ubi jalar kuning mempunyai kelebihan dibandingkan dengan ubi jalar kuning, antara lain: memiliki daya simpan yang lebih lama, mudah dicampur, dan lebih praktis. ${ }^{8}$

Untuk meningkatkan kandungan protein pada crackers, salah satu bahan makanan yang dapat ditambahkan adalah ikan teri nasi
(Stolephorus sp.). Kandungan protein dalam ikan teri nasi segar adalah $10,3 \mathrm{~g}$ per $100 \mathrm{~g}$. Ikan teri nasi tidak hanya sebagai sumber protein, tetapi juga sebagai sumber kalsium. Kandungan kalsium pada ikan teri nasi lebih tinggi daripada susu, yaitu $972 \mathrm{mg}$ per 100 g. ${ }^{9}$ Kalsium merupakan mineral yang dibutuhkan dalam masa pertumbuhan anakanak karena kalsium berfungsi untuk pembentukan tulang dan gigi. ${ }^{10}$

Substitusi tepung ubi jalar kuning dan ikan teri nasi pada crackers diharapkan akan meningkatkan kandungan gizi dan sifat organoleptik, sehingga dapat menjadi salah satu produk pangan alternatif untuk anak KEP dan KVA yang dapat diterima di masyarakat. Tujuan dari penelitian ini adalah untuk mengetahui pengaruh substitusi tepung ubi jalar kuning dan ikan teri nasi terhadap kadar protein, betakaroten, kalsium, dan uji kesukaan crackers.

\section{METODA}

Penelitian yang dilakuan ditinjau dari segi keilmuan termasuk dalam bidang ilmu Food Production, yang dilaksanakan mulai bulan Juli hingga September 2012 di Laboratorium Gizi Universitas Muhammadiyah Semarang dan Laboratorium Ilmu Pangan Universitas Katolik Soegijapranata Semarang.

Penelitian ini merupakan penelitian eksperimental dengan rancangan acak lengkap dua faktor yaitu substitusi tepung ubi jalar kuning (5\%, $10 \%$, dan 15\%) dan substitusi tepung ikan teri nasi (5\% dan 10\%) dengan 7 taraf perlakuan termasuk kontrol, 3 kali pengulangan, dan setiap pengukuran dilakukan secara simplo.

Crackers yang dibuat merupakan jenis nonflaky crackers, yang strukturnya tidak berlapislapis. ${ }^{11}$ Crackers dibuat menggunakan bahan baku tepung terigu, tepung ubi jalar kuning, tepung ikan teri nasi, margarin, gula, susu skim, ragi, garam, baking powder, kuning telur, dan air. Tepung terigu yang digunakan merk segitiga biru dan tepung ubi jalar kuning didapatkan dari PT. Rejeki Berkah Semarang. Tepung ubi jalar kuning yang digunakan telah memenuhi standar yang ditetapkan di Indonesia yaitu kadar air maksimal 10\%; tidak terdapat benda asing; dan tingkat kehalusan produk lolos ayakan 80 mesh. $^{8}$

Pada penelitian utama, data yang dikumpulkan dari variabel terikat yaitu kadar protein, betakaroten, kalsium dan uji kesukaan crackers dengan substitusi tepung ubi jalar kuning dan tepung ikan teri nasi. Kadar protein menggunakan metode Micro-Kjeldahl, kadar 
betakaroten menggunakan spektofotometri, dan kadar kalsium menggunakan metode permanganometri. ${ }^{12}$ Penilaian uji kesukaan untuk mengetahui tingkat kesukaan panelis terhadap crackers dengan substitusi tepung ubi jalar kuning dan tepung ikan teri nasi menggunakan uji hedonik dengan lima skala hedonik, yaitu $1=$ Sangat tidak suka, 2=Tidak suka, 3=Netral, 4=Suka, dan $5=$ Sangat suka. Penilaian uji kesukaan dilakukan pada 20 panelis agak terlatih, mahasiswa Program Studi Ilmu Gizi Fakultas Kedokteran Universitas Diponegoro dan dilakukan sebanyak 1 kali pengujian.

Data yang terkumpul selanjutnya dilakukan analisis menggunakan program statistik komputer.
Pengaruh variasi persentase substitusi tepung ubi jalar kuning dan tepung ikan teri nasi terhadap kadar protein, betakaroten, dan kalsium crackers diuji dengan Anova Two Ways. Analisis untuk mengetahui beda nyata perlakuan digunakan uji Tukey dan analisis pada uji kesukaan digunakan uji Friedman dengan uji lanjut uji Wilcoxon Signed Ranks Test.

\section{HASIL}

\section{Kadar Protein Crackers}

Hasil analisis kadar protein crackers dengan substitusi tepung ubi jalar kuning dan ikan teri nasi dapat dilihat pada Tabel 1 .

Tabel 1. Hasil Analisis Kadar Protein (\% per 100g) Crackers dengan Substitusi Tepung Ubi Jalar Kuning dan Ikan Teri Nasi

\begin{tabular}{|c|c|c|c|c|c|c|}
\hline & \multicolumn{4}{|c|}{ Substitusi Tepung Ubi Jalar Kuning } & \multirow{2}{*}{ Rerata } \\
\hline & & $0 \%$ & $5 \%^{a}$ & $10 \%{ }^{b}$ & $15 \%^{\mathrm{ab}}$ & \\
\hline \multirow{3}{*}{$\begin{array}{c}\text { Substitusi } \\
\text { Ikan Teri } \\
\text { Nasi }\end{array}$} & $0 \%$ & $9,00 \pm 1,42^{\mathrm{ab}}$ & & & & 9,00 \\
\hline & $5 \%$ & & $\begin{array}{c}10,25 \pm \\
1,26^{\mathrm{a}}\end{array}$ & $\begin{array}{c}7,13 \pm \\
0,44^{\mathrm{b}}\end{array}$ & $\begin{array}{c}6,96 \pm \\
0,52^{\mathrm{b}}\end{array}$ & 8,11 \\
\hline & $10 \%$ & & $7,57 \pm 0,56^{\mathrm{b}}$ & $\begin{array}{c}6,73 \pm \\
1,11^{\mathrm{b}} \\
\end{array}$ & $\begin{array}{c}7,57 \pm \\
0,82^{\mathrm{b}}\end{array}$ & 7,29 \\
\hline \multicolumn{2}{|c|}{ Rerata } & 9,00 & 8,91 & 6,93 & 7,265 & \\
\hline
\end{tabular}

Keterangan: huruf superscript yang berbeda pada parameter menunjukkan beda nyata dari analisis Anova Two Ways

Berdasarkan analisa statistik dengan Anova two ways menunjukkan bahwa substitusi tepung ikan teri nasi tidak meningkatkan kadar protein crackers secara bermakna $(\mathrm{p}=0,087)$, tetapi substitusi tepung ubi jalar kuning berpengaruh secara bermakna terhadap kadar protein $(\mathrm{p}=0,006)$ dan interaksi substitusi tepung ubi jalar kuning dan tepung ikan teri nasi berpengaruh secara bermakna terhadap kadar protein crackers $(\mathrm{p}=0,027)$.

Hanya crackers dengan substitusi tepung ubi jalar kuning 10\% yang berbeda nyata dengan crackers tanpa substitusi. Berdasarkan Tabel 1, kadar protein tertinggi terdapat pada crackers dengan substitusi tepung ubi jalar kuning 5\% tepung ikan teri nasi 5\%, dan kadar protein paling rendah pada crackers substitusi tepung ubi jalar kuning $10 \%$ tepung ikan teri nasi $10 \%$.

\section{Kadar Betakaroten Crackers}

Hasil analisis kadar betakaroten crackers dengan substitusi tepung ubi jalar kuning dan ikan teri nasi dapat dilihat pada Tabel 2.

Tabel 2. Hasil Analisis Kadar Betakaroten $(\mu \mathrm{g} / 100 \mathrm{~g})$ Crackers dengan Substitusi Tepung Ubi Jalar Kuning dan Ikan Teri Nasi

\begin{tabular}{|c|c|c|c|c|c|c|}
\hline & \multicolumn{4}{|c|}{ Substitusi Tepung Ubi Jalar Kuning } & \multirow{2}{*}{ Rerata } \\
\hline & & $\mathbf{0 \%}$ & $5 \%$ & $10 \%$ & $15 \%$ & \\
\hline \multirow{3}{*}{$\begin{array}{l}\text { Substitus } \\
\text { i Ikan } \\
\text { Teri Nasi }\end{array}$} & $\mathbf{0 \%}$ & $\begin{array}{c}60,00 \pm \\
16,64\end{array}$ & \multirow{3}{*}{$\begin{array}{c}84,67 \pm 6,11 \\
122,67 \pm \\
4,16\end{array}$} & \multirow{3}{*}{$\begin{array}{l}136,67 \pm 46,54 \\
109,00 \pm 33,04\end{array}$} & \multirow{3}{*}{$\begin{array}{l}115,33 \pm 21,22 \\
142,67 \pm 51,01\end{array}$} & 60,00 \\
\hline & $5 \%$ & & & & & 112,22 \\
\hline & $10 \%$ & & & & & 124,78 \\
\hline Rera & & 60,00 & 103,67 & 122,84 & 129,00 & \\
\hline
\end{tabular}


Berdasarkan analisa statistik dengan Anova two ways menunjukkan bahwa tidak ada peningkatan yang bermakna kadar betakaroten crackers dengan adanya substitusi tepung ubi jalar kuning $(\mathrm{p}=0,404)$, substitusi tepung ikan teri nasi $(\mathrm{p}=0,439)$, serta interaksi substitusi tepung ubi jalar kuning dan tepung ikan teri nasi $(\mathrm{p}=0,194)$.

\section{Kadar Kalsium Crackers}

Hasil analisis kadar kalsium crackers dengan substitusi tepung ubi jalar kuning dan ikan teri nasi dapat dilihat pada Tabel 3 .

Tabel 3. Hasil Analisis Kadar Kalsium (mg/100g) Crackers dengan Substitusi Tepung Ubi Jalar Kuning dan Ikan Teri Nasi

\begin{tabular}{rcccccc}
\hline & & \multicolumn{3}{c}{ Substitusi Tepung Ubi Jalar Kuning } & \multirow{2}{*}{ Rerata } \\
\cline { 3 - 5 } & & $\mathbf{0 \%}^{\mathbf{d}}$ & $\mathbf{5 \%}^{\mathbf{c}}$ & $\mathbf{1 0 \%}^{\mathbf{b}}$ & $\mathbf{1 5 \%}^{\mathbf{a}}$ & \\
\hline & \multirow{2}{*}{$\mathbf{0 \%}^{\mathbf{c}}$} & $2,96 \pm$ & & & & 2,96 \\
Substitusi & 0,17 & & & & \\
Ikan Teri & $\mathbf{5 \%}^{\mathbf{b}}$ & & $28,55 \pm$ & $36,79 \pm$ & $40,99 \pm$ & 35,44 \\
Nasi & & & 0,98 & 0,13 & 2,07 & \\
& $\mathbf{1 0 \%}^{\mathbf{a}}$ & & $32,57 \pm$ & $42,18 \pm$ & $46,07 \pm$ & 40,27 \\
& Rerata & 2,96 & 0,47 & 0,58 & 1,06 & \\
\hline
\end{tabular}

Keterangan: huruf superscript yang berbeda pada parameter menunjukkan beda nyata dari analisis Anova Two Ways

Berdasarkan analisa statistik dengan Anova two ways menunjukkan bahwa interaksi substitusi tepung ubi jalar kuning dan tepung ikan teri nasi tidak meningkatkan kadar kalsium crackers $(\mathrm{p}=0,476)$, tetapi substitusi tepung ubi jalar kuning meningkatkan kadar kalsium crackers $(\mathrm{p}=0,000)$ dan substitusi tepung ikan teri nasi juga meningkatkan kadar kalsium crackers $(\mathrm{p}=0,000)$.

\section{Uji Kesukaan}

\section{a. Tekstur}

Hasil analisis uji kesukaan tekstur crackers dengan substitusi tepung ubi jalar kuning dan ikan teri nasi dapat dilihat pada Tabel 4.

Tabel 4. Hasil Analisis Uji Kesukaan pada Tekstur Crackers dengan Substitusi Tepung Ubi Jalar Kuning dan Ikan Teri Nasi

\begin{tabular}{cccccc}
\hline & & \multicolumn{4}{c}{ Substitusi Tepung Ubi Jalar Kuning } \\
\cline { 3 - 5 } & $\mathbf{0 \%}$ & $\mathbf{5 \%}$ & $\mathbf{1 0 \%}$ & $\mathbf{1 5 \%}$ \\
\hline & $\mathbf{0 \%}$ & $\begin{array}{c}4,55 \pm 0,61 \\
\text { (sangat } \\
\text { suka) }\end{array}$ & & & \\
$\begin{array}{c}\text { Substitusi } \\
\text { Ikan Teri } \\
\text { Nasi }\end{array}$ & $\mathbf{5 \%}$ & & $\begin{array}{c}4,35 \pm 0,67 \\
\text { (suka) }\end{array}$ & $\begin{array}{c}4,00 \pm 1,08 \\
\text { (suka) }\end{array}$ & $\begin{array}{c}4,30 \pm 1,03 \\
\text { (suka) }\end{array}$ \\
& $\mathbf{1 0 \%}$ & & $\begin{array}{c}3,95 \pm 1,23 \\
\text { (suka) }\end{array}$ & $\begin{array}{c}4,20 \pm 1,19 \\
\text { (suka) }\end{array}$ & $\begin{array}{c}4,40 \pm 0,82 \\
\text { (suka) }\end{array}$ \\
\hline
\end{tabular}

Hasil uji kesukaan terhadap tekstur crackers tanpa substitusi memiliki tingkat kesukaan tertinggi yaitu 4,55 (sangat suka), sedangkan crackers dengan substitusi tepung ubi jalar kuning 5\% dan tepung ikan teri nasi $10 \%$ memiliki tingkat kesukaan terendah yaitu 3,95 (suka). Uji statistik dengan nilai $\mathrm{p}=0,238$ menunjukkan substitusi tepung ubi jalar kuning dan ikan teri nasi tidak berpengaruh terhadap uji kesukaan tekstur crackers.

b. Aroma

Hasil analisis uji kesukaan aroma crackers dengan substitusi tepung ubi jalar kuning dan ikan teri nasi dapat dilihat pada Tabel 5. 
Tabel 5. Hasil Analisis Uji Kesukaan pada Aroma Crackers dengan Substitusi Tepung Ubi Jalar Kuning dan Ikan Teri Nasi

\begin{tabular}{|c|c|c|c|c|c|}
\hline & \multicolumn{4}{|c|}{ Substitusi Tepung Ubi Jalar Kuning } \\
\hline & & $0 \%$ & $5 \%$ & $10 \%$ & $15 \%$ \\
\hline & $\mathbf{0 \%}$ & $\begin{array}{l}4,40 \pm 0,82^{\mathrm{a}} \\
\quad(\text { suka })\end{array}$ & & & \\
\hline $\begin{array}{l}\text { Substitusi } \\
\text { Ikan Teri }\end{array}$ & $5 \%$ & & $\begin{array}{c}3,05 \pm \\
1,36^{\mathrm{c}} \\
\text { (netral) }\end{array}$ & $\begin{array}{l}3,95 \pm \\
1,19^{\text {ac }} \\
\text { (suka) }\end{array}$ & $\begin{array}{l}4,10 \pm \\
1,25^{\mathrm{ab}} \\
\text { (suka) }\end{array}$ \\
\hline Nasi & $10 \%$ & & $\begin{array}{l}3,85 \pm \\
0,88^{\mathrm{ab}} \\
\text { (suka) }\end{array}$ & $\begin{array}{l}3,95 \pm \\
1,19^{\mathrm{ab}} \\
\text { (suka) }\end{array}$ & $\begin{array}{l}3,75 \pm \\
1,07^{\text {bc }} \\
\text { (suka) }\end{array}$ \\
\hline
\end{tabular}

Keterangan: huruf superscript yang berbeda pada parameter menunjukkan beda nyata dari analisis Friedman

Hasil uji kesukaan terhadap aroma crackers tanpa substitusi memiliki tingkat kesukaan tertinggi yaitu 4,40 (suka), sedangkan crackers dengan substitusi tepung ubi jalar kuning $5 \%$ dan tepung ikan teri nasi 5\% memiliki tingkat kesukaan terendah yaitu 3,05 (netral). Uji statistik menunjukkan bahwa substitusi tepung ubi jalar kuning dan tepung ikan teri nasi berpengaruh terhadap uji kesukaan aroma yang ditunjukkan dengan nilai $\mathrm{p}=0,020$.

c. Rasa

Hasil analisis uji kesukaan rasa crackers dengan substitusi tepung ubi jalar kuning dan ikan teri nasi dapat dilihat pada Tabel 6.

Tabel 4. Hasil Analisis Uji Kesukaan pada Rasa Crackers dengan Substitusi Tepung Ubi Jalar Kuning dan Ikan Teri Nasi

\begin{tabular}{|c|c|c|c|c|c|}
\hline & & \multicolumn{4}{|c|}{ Substitusi Tepung Ubi Jalar Kuning } \\
\hline & & $0 \%$ & $5 \%$ & $10 \%$ & $15 \%$ \\
\hline & $\mathbf{0 \%}$ & $\begin{array}{l}4,45 \pm 1,15^{\mathrm{a}} \\
\text { (suka) }\end{array}$ & & & \\
\hline $\begin{array}{l}\text { Substitusi } \\
\text { Ikan Teri } \\
\text { Nasi }\end{array}$ & $5 \%$ & & $\begin{array}{c}2,85 \pm \\
1,49^{\mathrm{c}} \\
\text { (netral) }\end{array}$ & $\begin{array}{c}4,05 \pm \\
1,15^{\text {ab }} \\
\text { (suka) }\end{array}$ & $\begin{array}{l}3,50 \pm \\
1,28^{\mathrm{bc}} \\
\text { (suka) }\end{array}$ \\
\hline & $10 \%$ & & $\begin{array}{l}3,90 \pm \\
1,07^{\mathrm{ab}} \\
\text { (suka) }\end{array}$ & $\begin{array}{l}3,85 \pm \\
1,04^{\mathrm{bc}} \\
\text { (suka) }\end{array}$ & $\begin{array}{l}3,55 \pm \\
1,15^{\mathrm{bc}} \\
\text { (suka) }\end{array}$ \\
\hline
\end{tabular}

Keterangan: huruf superscript yang berbeda pada parameter menunjukkan beda nyata dari analisis Friedman

Hasil uji kesukaan terhadap rasa crackers tanpa substitusi memiliki tingkat kesukaan tertinggi yaitu 4,45 (suka), sedangkan crackers dengan substitusi tepung ubi jalar kuning 5\% dan tepung ikan teri nasi 5\% memiliki tingkat kesukaan terendah yaitu 2,85 (netral). Substitusi tepung ubi jalar kuning dan ikan teri nasi berpengaruh terhadap uji kesukaan rasa crackers ditunjukkan dengan nilai $\mathrm{p}=0,003$.

\section{d. Warna}

Hasil analisis uji kesukaan warna crackers dengan substitusi tepung ubi jalar kuning dan ikan teri nasi dapat dilihat pada Tabel 7. 
Tabel 7. Hasil Analisis Uji Kesukaan pada Warna Crackers dengan Substitusi Tepung Ubi Jalar Kuning dan Ikan Teri Nasi

\begin{tabular}{cccccc}
\hline & \multicolumn{4}{c}{ Substitusi Tepung Ubi Jalar Kuning } \\
\cline { 3 - 6 } & $\mathbf{0 \%}$ & $\mathbf{5 \%}$ & $\mathbf{1 0 \%}$ & $\mathbf{1 5 \%}$ \\
\hline & $\mathbf{0 \%}$ & $\begin{array}{c}4,60 \pm 0,68^{\mathrm{a}} \\
\text { (sangat } \\
\text { suka) }\end{array}$ & & \\
& & & & \\
Substitusi & & & $3,45 \pm$ & $3,95 \pm$ & $3,50 \pm$ \\
Ikan Teri & $\mathbf{5 \%}$ & & $1,28^{\mathrm{c}}$ & $0,99^{\mathrm{b}}$ & $1,15^{\mathrm{bc}}$ \\
Nasi & & & $($ netral) & $($ suka) & $($ suka) \\
& & & $3,90 \pm$ & $3,45 \pm$ & $4,00 \pm$ \\
& $\mathbf{1 0 \%}$ & & $1,02^{\mathrm{b}}$ & $1,23^{\mathrm{bc}}$ & $1,08^{\mathrm{ab}}$ \\
& & & $($ suka) & $($ netral $)$ & $($ suka) \\
\hline
\end{tabular}

Keterangan: huruf superscript yang berbeda pada parameter menunjukkan beda nyata dari analisis Friedman

Hasil uji kesukaan terhadap warna crackers tanpa substitusi memiliki tingkat kesukaan tertinggi yaitu 4,60 (sangat suka), sedangkan crackers dengan substitusi tepung ubi jalar kuning 5\% tepung ikan teri nasi 5\% dan substitusi tepung ubi jalar kuning $10 \%$ dan tepung ikan teri nasi $10 \%$ memiliki tingkat kesukaan terendah yaitu 3,45 (netral). Uji statistik dengan nilai $\mathrm{p}=0,000$ menunjukkan substitusi tepung ubi jalar kuning dan ikan teri nasi berpengaruh terhadap uji kesukaan warna crackers.

\section{PEMBAHASAN}

\section{A. Kadar Protein}

Crackers yang disubstitusi tepung ubi jalar kuning 5\% dan tepung ikan teri nasi 5\% memiliki kadar protein tertinggi yaitu $10,25 \%$ per $100 \mathrm{~g}$ sedangkan kadar protein terendah terdapat pada crackers yang disubstitusi tepung ubi jalar kuning $10 \%$ dan tepung ikan teri nasi $10 \%$ yaitu $6,73 \%$ per $100 \mathrm{~g}$. Substitusi tepung ikan teri nasi tidak meningkatkan kadar protein crackers secara bermakna karena sedikitnya substitusi tepung ikan teri nasi. Kadar protein tepung ikan teri nasi sebesar $71,43 \%$ per $100 \mathrm{~g}$, sehingga substitusi ikan teri nasi hanya menyumbang protein sebesar $3,57 \%$ pada crackers dengan substitusi tepung ikan teri nasi 5\% dan $7,14 \%$ pada crackers dengan substitusi tepung ikan teri nasi $10 \%$. Substitusi tepung ubi jalar kuning berpengaruh terhadap kadar protein karena kadar protein tepung ubi jalar kuning lebih rendah dibandingkan tepung terigu. Kadar protein tepung terigu dan tepung ubi jalar kuning yang digunakan pada penelitian ini sebesar $11,5 \%$ per $100 \mathrm{~g}$ dan $1,57 \%$ per $100 \mathrm{~g}$.
Semakin banyak tepung terigu yang disubstitusi dengan tepung ubi jalar kuning, maka semakin rendah kadar proteinnya.

Pada proses pengolahan crackers yang menggunakan pemanasan terjadi kehilangan protein. Kehilangan protein selama pengolahan pada penelitian ini berkisar antara $12-56,66 \%$. Kehilangan protein karena proses pemanasan dikenal dengan nama reaksi Maillard. Reaksi Maillard merupakan reaksi antara gula pereduksi dengan protein pada suhu $150-260^{\circ} \mathrm{C}$ yang menyebabkan warna cokelat pada makanan. Pada reaksi ini, asam-asam amino terutama lisin berikatan dengan glukosa dan fruktosa membentuk produk akhir melanoidin, protein termodifikasi dan senyawa aromatik seperti trimetil pirazin, tetrametil pirazin, benzaldehida, fenil asetaldehida dan senyawa lainnya yang merupakan sumber aroma yang khas pada produk reaksi Maillard dan bersifat volatil sehingga dapat menguap dan menyebabkan penurunan kadar protein pada makanan. ${ }^{13}$

Nilai gizi protein dipengaruhi oleh dua faktor, yaitu daya cerna dan jumlah dan komposisi asam-asam amino esensial. Nilai gizi protein hewani lebih tinggi dibandingkan dengan protein nabati. Protein hewani merupakan sumber protein yang lengkap dan bermutu tinggi, karena mempunyai kandungan asam-asam amino esensial yang lengkap yang susunannya mendekati yang diperlukan tubuh, serta daya cernanya tinggi sehingga jumlah yang dapat diserap tubuh juga tinggi. ${ }^{13}$ Tepung ikan teri nasi memiliki kandungan asam amino lisin yang tinggi yaitu sebesar $67,4 \mathrm{mg} / \mathrm{g} \mathrm{N}$, sedangkan asam amino pembatas tepung ubi 
jalar kuning adalah asam amino lisin. Asam amino lisin pada ubi jalar kuning sebesar $6,08 \mathrm{mg} / \mathrm{g}$ N. Dengan substitusi tepung ikan teri nasi diharapkan dapat melengkapi kekurangan asam amino lisin pada tepung ubi jalar kuning dalam pembuatan crackers.

\section{B. Kadar Betakaroten}

Crackers dengan substitusi tepung ubi jalar kuning dan ikan teri nasi memiliki kadar betakaroten lebih tinggi dibandingkan dengan crackers berbahan dasar $100 \%$ tepung terigu. Kadar betakaroten pada crackers tanpa substitusi sebesar $60 \mu \mathrm{g} / 100 \mathrm{~g}$ dan kadar betakaroten tertinggi terdapat pada crackers dengan substitusi tepung ubi jalar kuning 15\% dan tepung ikan teri nasi $10 \%$ yaitu $142,67 \mu \mathrm{g} / 100 \mathrm{~g}$. Substitusi tepung ubi jalar kuning dan tepung ikan teri nasi tidak berpengaruh secara bermakna terhadap peningkatan kadar betakaroten crackers. Hal ini dikarenakan sedikitnya substitusi tepung ubi jalar kuning dan tepung ikan teri nasi. Berdasarkan hasil analisis, kadar betakaroten pada tepung terigu, tepung ubi jalar kuning, dan tepung ikan teri nasi dalam penelitian ini secara berturut-turut sebesar $0,01 \mu \mathrm{g} / 100 \mathrm{~g}$, $550,25 \mu \mathrm{g} / 100 \mathrm{~g}$, dan $0,014 \mu \mathrm{g} / 100 \mathrm{~g}$.

Ubi jalar kuning mengandung betakaroten cukup tinggi. Proses pengolahan crackers dapat menyebabkan penurunan dan kerusakan betakaroten. Faktor-faktor yang menyebabkan penurunan dan kerusakan betakaroten yaitu oksigen, cahaya, dan panas. Betakaroten mudah teroksidasi ketika terkena udara. Hal ini disebabkan karena adanya struktur ikatan rangkap pada molekul betakaroten. Oksidasi akan berlangsung lebih cepat dengan adanya cahaya, pemanasan dengan suhu tinggi, dan katalis logam. Penurunan kadar betakaroten juga dapat terjadi jika waktu proses pemanasan lebih lama. ${ }^{14}$ Pada penelitian ini, terdapat proses pemanasan yaitu pemanggangan crackers. Proses pemanggangan dengan suhu tinggi dapat menurunkan kadar betakaroten serta memungkinkan produk terpapar oksigen yang akan menyebabkan oksidasi enzimatis terhadap betakaroten oleh enzim lipoksigenase yang menyebabkan kerusakan molekul betakaroten all-trans. Jumlah penurunan betakaroten akan semakin besar seiring dengan bertambahnya suhu dan waktu pemanggangan. Selain proses pemanggangan, adanya kontak dengan udara bebas pada saat proses penggilingan dan pencetakan adonan crackers dapat menyebabkan terjadinya oksidasi yang berperan dalam menurunkan kadar betakaroten. ${ }^{15}$

\section{Kadar Kalsium}

Crackers dengan substitusi ubi jalar kuning dan ikan teri nasi memiliki kadar kalsium lebih tinggi dibandingkan dengan crackers tanpa substitusi. Kadar kalsium crackers tanpa substitusi sebesar 2,96mg/100g, sedangkan kadar kalsium tertinggi terdapat pada crackers dengan substitusi tepung ubi jalar kuning $15 \%$ dan tepung ikan teri nasi $10 \%$ yaitu sebesar 46,07mg/100g. Kadar kalsium tepung terigu, tepung ubi jalar kuning, dan tepung ikan teri nasi secara berturut-turut yaitu sebesar $15,68 \mathrm{mg} / 100 \mathrm{~g}, \quad 22,88 \mathrm{mg} / 100 \mathrm{~g}, \quad$ dan $645,36 \mathrm{mg} / 100 \mathrm{~g}$. Sumber kalsium dalam pembuatan crackers ini sebagian besar berasal dari tepung ikan teri nasi. Crackers dengan substitusi tepung ikan teri nasi $10 \%$ mengandung kalsium yang lebih tinggi disbanding dengan crackers substitusi tepung ikan teri nasi $5 \%$. Hal ini menunjukkan bahwa semakin tinggi substitusi tepung ikan teri nasi maka semakin meningkat kadar kalsium pada crackers. Kadar kalsium dalam bahan makanan tidak terpengaruh oleh proses pengolahan. ${ }^{16}$

Kalsium memiliki peranan penting di dalam tubuh terutama untuk pembentukan tulang dan gigi. Kalsium dibutuhkan oleh anakanak dan remaja untuk proses pertumbuhan. Asupan kalsium yang mencukupi kebutuhan dapat memaksimalkan kemampuan tulang mencapai kepadatan optimal dan mencegah terjadinya pengeroposan tulang pada masa dewasa. Sumber kalsium berasal dari hewan dan tumbuhan. Kalsium didapat dari susu dan olahan susu, ikan, sayuran hijau (brokoli, kol hijau, lobak hijau, bok choy, dan bayam). ${ }^{17}$

\section{Uji Kesukaan}

\section{Tekstur}

Crackers memiliki tekstur yang renyah. Hasil uji kesukaan terhadap tekstur menunjukkan crackers tanpa substitusi memiliki tingkat kesukaan tertinggi yaitu 4,55 (sangat suka), sedangkan crackers dengan substitusi tepung ubi jalar kuning $5 \%$ dan tepung ikan teri nasi $10 \%$ memiliki tingkat kesukaan terendah yaitu 3,95 (suka). Hasil uji statistik Friedman menunjukkan bahwa tidak terdapat pengaruh substitusi tepung ubi jalar kuning dan ikan teri nasi pada tingkat kesukaan panelis terhadap tekstur. 
Crackers dengan substitusi tepung ubi jalar kuning dan ikan teri nasi memiliki tekstur yang agak keras, tetapi masih disukai oleh panelis. Hal ini dikarenakan tepung ubi jalar kuning dan tepung ikan teri nasi tidak mengandung gluten. Gluten pada adonan crackers hanya berasal dari tepung terigu. Gluten terbentuk karena adanya pencampuran protein gliadin dan glutein yang terdapat pada tepung terigu pada saat pengadukan adonan. Jika gluten dicampur dengan air, maka volumenya akan membesar. Selama pemanggangan, udara dan uap air akan terperangkap di dalam adonan, sehingga adonan akan mengembang. Dengan adanya substitusi tepung ubi jalar kuning dan ikan teri nasi pada crackers maka kandungan gluten lebih sedikit karena berkurangnya penggunaan tepung terigu. Crackers yang dihasilkan agak keras karena volume pengembangan semakin rendah. ${ }^{11}$

\section{Aroma}

Aroma crackers substitusi tepung ubi jalar kuning dan tepung ikan teri nasi pada penelitian ini memiliki tingkat kesukaan suka hingga netral. Berdasarkan hasil uji kesukaan, tingkat kesukaan tertinggi adalah crackers tanpa substitusi, sedangkan crackers dengan substitusi tepung ubi jalar kuning 5\% dan tepung ikan teri nasi 5\% memiliki nilai tingkat kesukaan terendah. Pada crackers yang disubstitusi tepung ubi jalar kuning dan ikan teri nasi memiliki aroma harum khas ubi jalar kuning dan aroma amis yang kuat. Aroma amis pada crackers disebabkan oleh tepung ikan teri nasi yang digunakan. Aroma amis merupakan aroma khas pada ikan yang disebabkan oleh komponen nitrogen yaitu guanidin, trimetil amin oksida (TMAO), dan turunan imidazol. ${ }^{18}$

\section{Rasa}

Hasil analisis uji kesukaan panelis terhadap rasa menunjukkan crackers tanpa substitusi memiliki tingkat kesukaan tertinggi dengan nilai rerata 4,45 , sedangkan crackers dengan substitusi tepung ubi jalar kuning 5\% dan tepung ikan teri nasi 5\% memiliki tingkat kesukaan terendah dengan rerata 2,85. Crackers yang disubstitusi tepung ubi jalar kuning dan tepung ikan teri nasi memiliki rasa yang gurih. Substitusi tepung ikan teri menghasilkan rasa khas teri yang sangat kuat yang menyebabkan rasa khas ubi kurang terasa. Rasa yang gurih lebih disukai panelis, dibuktikan dengan hasil analisis uji kesukaan rasa crackers menunjukkan ada pengaruh yang signifikan.

\section{Warna}

Berdasarkan hasil uji kesukaan terhadap warna crackers menunjukkan bahwa crackers yang paling disukai adalah crackers tanpa substitusi dan yang kurang disukai panelis adalah crackers dengan substitusi tepung ubi jalar kuning 5\% tepung ikan teri nasi $5 \%$ dan substitusi tepung ubi jalar kuning 10\% tepung ikan teri $10 \%$. Substitusi tepung ubi jalar kuning dan tepung ikan teri nasi menghasilkan crackers berwarna kuning kecokelatan. Warna crackers yang dihasilkan berasal dari tepung ubi jalar kuning dan tepung ikan teri nasi yang digunakan. Tepung ubi jalar kuning berwarna kuning, sedangkan tepung ikan teri nasi berwarna kecokelatan. Semakin banyak substitusi tepung ikan teri nasi, warna crackers akan semakin cokelat. Selain karena penggunaan tepung ikan teri nasi, warna kecokelatan pada crackers juga diakibatkan karena adanya reaksi browning. Reaksi browning terjadi akibat bereaksinya lisin (tepung ikan teri nasi) dengan gula sederhana (gula tepung) pada suhu tinggi. ${ }^{19}$

\section{SIMPULAN}

1. Substitusi tepung ikan teri nasi tidak meningkatkan kadar protein crackers, tetapi substitusi tepung ubi jalar kuning dan interaksi substitusi tepung ubi jalar kuning dan tepung ikan teri nasi berpengaruh terhadap kadar protein crackers.

2. Substitusi tepung ubi jalar kuning, substitusi tepung ikan teri nasi, serta interaksi substitusi tepung ubi jalar kuning dan tepung ikan teri nasi tidak meningkatkan kadar betakaroten crackers.

3. Interaksi substitusi tepung ubi jalar kuning dan tepung ikan teri nasi tidak meningkatkan kadar kalsium crackers, tetapi substitusi tepung ubi jalar kuning meningkatkan kadar kalsium crackers dan substitusi tepung ikan teri nasi juga meningkatkan kadar kalsium crackers

4. Uji kesukaan (tekstur, aroma, rasa, dan warna) crackers dengan substitusi tepung 
ubi jalar kuning dan tepung ikan teri nasi lebih rendah dari crackers kontrol, tetapi masih disukai oleh panelis.

5. Berdasarkan nilai gizi dan uji kesukaan, crackers yang direkomendasikan adalah crackers dengan substitusi tepung ubi jalar kuning $15 \%$ dan tepung ikan teri nasi $10 \%$.

\section{SARAN}

Untuk meningkatkan uji kesukaan crackers dapat ditambahkan keju. Selain itu, keju juga memiliki protein yang tinggi sehingga dapat meningkatkan kadar protein crackers.

\section{DAFTAR PUSTAKA}

1. Combs, GF. The Vitamins, $3^{\text {rd }}$ Ed. USA: Elsevier, Inc. 2008. p96,113,131

2. Kementrian Kesehatan Republik Indonesia. Laporan Hasil Riset Kesehatan Dasar. 2010

3. Solihin Pudjiadi. Ilmu Gizi Klinis pada Anak, $4^{\text {th }}$ Ed. Jakarta: Fakultas Kedokteran Universitas Indonesia. 2005

4. Bernatal Sarigih. Analisis Kebijakan Penanganan Masalah Gizi di Kalimantan Timur Berdasarkan Pengalaman Berbagai Negara. Borneo Administrator Vol. 6 No.3 Tahun 2010. p2140-2160

5. Dewan Ketahanan Pangan Departemen Pertanian RI. World Food Programme: Peta Ketahanan dan Kerentanan Pangan Indonesia 2009. Jakarta: PT. Enka Deli. 2009

6. Jaarsveld, PJV. Faber, M. Tanumihardjo, SA. Nestel, P. Lambard, CJ. Benade, AJS. Betakarotenrich orange-fleshed sweet potato improves the vitamin A status of primary school children assessed with the modified-relative-dose-response test. Am J Clin Nutr 2005;81:1080-7

7. Voughan, LA. Manore, MM. Thompson, JL. The Science of Nutrition. USA: Pearson Education,Inc. 2011
8. Indrie Ambarsari. Sarjana. Abdul Choliq. Rekomendasi dalam Penetapan Standar Mutu Tepung Ubi Jalar. Jawa Tengah. 2009

9. Persatuan Ahli Gizi Indonesia. Tabel Komposisi Pangan Indonesia. Jakarta; Elex Media Komputindo. 2009

10. Rolfes, SR. Pinna, K. Whitney, E. Understanding Normal and Clinical Nutrition $8^{\text {th }} e d$. USA: Wadsworth. 2009

11. Susilawati. Medikasari. Kajian Formulasi Tepung Terigu dan Tepung dari berbagai jenis Ubi Jalar Sebagai Bahan Dasar Pembuatan Biskuit Non-Flaky rackers. Prosiding Seminar Nasional Sains dan Teknologi II 2008. Universitas Lampung. 2008

12. Abdul Rohman. Sumantri. Analisis Makanan. Yogyakarta; Gadjah Mada University Press. 2007

13. Deddy Muchtadi. Teknik Evaluasi Nilai Gizi Protein. Bandung: Alfabeta. 2010. p13-22, 80-86

14. Christina Mumpuni Erawati. Kendali Stabilitas Betakaroten Selama Proses Produksi Tepung Ubi Jalar (Ipomoea batatas L.). [tesis]. Bogor: Sekolah Pascasarjana Institut Pertanian Bogor. 2006

15. Chi-Ho, L. Jin-Kook, C. Seung, JL. Wonbang, K. Woojoon, P. Chang-Han, K. Enhancing $\beta$-carotene content in asian noodles by adding pumpkin powder. Cereal Chem 2002;79(4):593-5

16. Tien R Muchtadi. Fitriyono Ayustaningwarno. Teknologi Proses Pengolahan Pangan. Bandung: Alfabeta. 2010. p12

17. Rolfes, SR. Pinna, K. Whitney, E. Understanding Normal and Clinical Nutrition $7^{\text {th }}$ ed. USA. Thomson Wadsworth.2006. p438-44

18. Suseno S. Pipit S. Darma SW. Pengaruh penambahan Daging Lumat Ikan Nilem (Ostheochilus hasselti) pada pembuatan Simping sebagai makanan camilan. Bulletin teknologi hasil perikanan Vol VII No 1 Tahun 2004. Jakarta

19. Winarno FG. 1997. Kimia Pangan dan Gizi. Jakarta: Gramedia Pustaka Utama. p59 